\title{
The cooperation between suppliers and an agro-industrial slaughterhouse: a measurement tool
}

\author{
João Cuareli Alécio ${ }^{\mathrm{a}}$, Alvaro Neuenfeldt Júnior ${ }^{\mathrm{a} *}$ (D), Julio Siluk ${ }^{\mathrm{a}}$, Angélica Alebrant Mendes ${ }^{\mathrm{a}}$, \\ Bruna Rigon de Oliveira ${ }^{a}$, Mário Mello ${ }^{a}$ \\ ${ }^{a}$ Universidade Federal de Santa Maria, Santa Maria, RS, Brasil
}

*alvjr2002@hotmail.com

\begin{abstract}
Paper aims: To identify factors to measure the cooperation between an agro-industrial pork slaughterhouse cooperative and input suppliers.

Originality: A performance measurement tool applicable in real-life industry practices related to input suppliers, based on critical success factors.

Research method: The performance measurement tool was calculated based on the analytic hierarchy process (AHP) procedure, constituted by two essential elements, the critical success factors and the key performance indicators, organized in a hierarchical structure. The key performance indicators are used to detail the critical success factors, measuring the supplier's performance in relation to specific cooperation characteristics.

Main findings: In general, 77\% of suppliers are fully or potentially cooperative with an established performance in risk sharing and information sharing factors. For the remaining $23 \%$ of suppliers classified as partially cooperatives, suggestions were proposed for changes to be implemented which improve their cooperation level performance. Finally, a direct relation between a low proportion of input discards and a established cooperative performance between suppliers and the analyzed agro-industrial pork cooperative was not verified.

Implications for theory and practice: To provide a performance measurement tool developed with methodological rigor to be used by researchers and agro-industrial pork slaughterhouse cooperative managers to improve the Brazilian pork slaughterhouse supply chain context.

Keywords

Agro-industrial slaughterhouse. Supply chain management. Critical success factors. Key performance indicators. Analytic hierarchy process.
\end{abstract}

How to cite this article: Alécio, J. C., Neuenfeldt Júnior, A., Siluk, J., Mendes, A. A., Oliveira, B. R., \& Mello, M. (2021). The cooperation between suppliers and an agro-industrial slaughterhouse: a measurement tool. Production, 31, e20200069. https://doi.org/10.1590/0103-6513.20200069.

Received: July 15, 2020; Accepted: May 7, 2021.

\section{Introduction}

In any agro-industrial sector, the cooperation between input suppliers and agro-industrial cooperatives is essential to achieve greater productivity and reduce losses in the production systems. The specifications and the quality of the inputs, with deliveries that comply with exactly what was agreed in the supply contract, have a strong impact on productivity, adding greater value to the chains of all agro-industrial sectors.

The competitiveness of a food supply chain is determined by the ability to develop successful partnerships in agribusiness, and a relationship between suppliers and agro-industrial cooperatives is essential to achieve success in supply chain management. One way to improve the supply service quality is to increase cooperation between the agro-industry and suppliers to coordinate supply collaboration and achieve mutually beneficial goals (Ziggers \& Trienekens, 1999; Flynn et al., 2010; Jasti \& Kodali, 2015; Sjauw-Koen-Fa et al., 2016). However, in general, 
the real perceptions of non-fully competitive suppliers' effects in the agro-industrial cooperatives supply chain are not known by managers, due to the lack of understanding about lean manufacturing philosophy and lean supply chain management work culture.

Improvement in the cooperation when using lean supply chain management concepts must be applied broadly, as a complete business system, integrating the operation from the first suppliers until the customers (Grasso, 2005; Womack \& Jones, 2005; Kennedy \& Widener, 2008). Wiengarten et al. (2013) describes examples of lean supply chain management practices between suppliers and a cooperative to consolidate acquisitions, supplier's certifications, and specifically to measure the quality of service provided, analyzing not only the quality of the input delivered but also the relationship between the supplier and the cooperative in the development of products and management practices. Using lean supply chain management concepts as a basis for cooperation increases competitiveness for the whole chain, achieving improvements in productivity and reduction in the costs to develop new products for consumers and to control the input supply operations (Larson \& Greenwood, 2004; Singh \& Pandey, 2015; Abreu et al., 2017).

The performance of supply chain cooperation is the result of policies and procedures related to several critical factors. The main question is "How to design metrics to manage cooperation in a supply chain while recognizing that the organizations in the chain are components of complex and interconnected systems?". Based on these premises, the research focus aims to identify factors to measure the cooperation between an agro-industrial pork slaughterhouse cooperative and input suppliers, considering the importance of lean supply chain management for competitive advantage. In this context, key performance indicators (KPls) were developed based on lean supply chain management factors related to the cooperation level, trust, and recognition of each supplier for the inputs' supply system.

The main contributions of this paper are (a) to provide a systematic method for measuring the input supplier cooperation that can be applied to any agro-industrial pork slaughterhouse cooperative context, regardless of the number of different inputs provided by the supplier; (b) to verify the relation between a low proportion of discards and a high cooperative performance between input suppliers and the analyzed agro-industrial pork slaughterhouse cooperative; and (c) to study the impact of lean supply chain management factors, such as information and risk-sharing contracts, on cooperation between the agro-industrial pork slaughterhouse cooperative and input suppliers.

Agribusiness is fundamental to support social and economic development in Brazil. According to Associação Brasileira das Indústrias Exportadoras de Carne (2019), the economic activities of agribusiness in 2018 generated a gross domestic product (GDP) equal to U\$ 119.44 billion, 8.30\% higher when compared to 2017. The main Brazilian agro-industrial pork slaughterhouse cooperatives are related to the production of beef, poultry, and pork. The Southern region has the largest production in Brazil, 59.70\% of the total, producing more than 857 million units per year. For pork production, the Southern region represented $65.31 \%$ of all Brazilian production in 2018 (Associação Brasileira das Indústrias Exportadoras de Carne, 2019). Concerning the world scenario of pork production, Brazil is the fourth-largest producer and exporter in the world. Brazilian protein reaches more than 70 countries, recognized as a quality product by demanding international markets, and competing with international competitors.

Due to the high level of perishability, raw material's inventory costs, and final products, the agro-industrial pork slaughterhouse cooperative supply chain is characterized as make-to-order (MT0), where sales requisition by customers is essential to determine the system production rate and minimize waste and inventory, increasing the customer's services competitiveness.

The study is structured in six sections. In Section 1, an introduction with the goal and justifications for the development of the research is shown. The research protocol is presented in Section 2. A theoretical review about the main literature on the topic is proposed in Section 3. The modeling construction is present in Section 4, where the performance measurement is exposed step by step. Section 5 focuses on the application of the measurement with the results obtained. Finally, Section 6 shows the conclusions reached from the study.

\section{Research protocol}

The protocol with procedures organized in stages was elaborated to facilitate how the research was developed, as shown in Figure 1.

The problem contextualization was proposed in the introduction section (Section 1) to present relevant aspects about the context related to cooperation between an agro-industrial pork slaughterhouse cooperative and input suppliers. For theoretical reference (Section 3), a survey based on technical reports and scientific articles is briefly described in the topics below. The ScienceDirect and Web of Science websites were used, giving access 


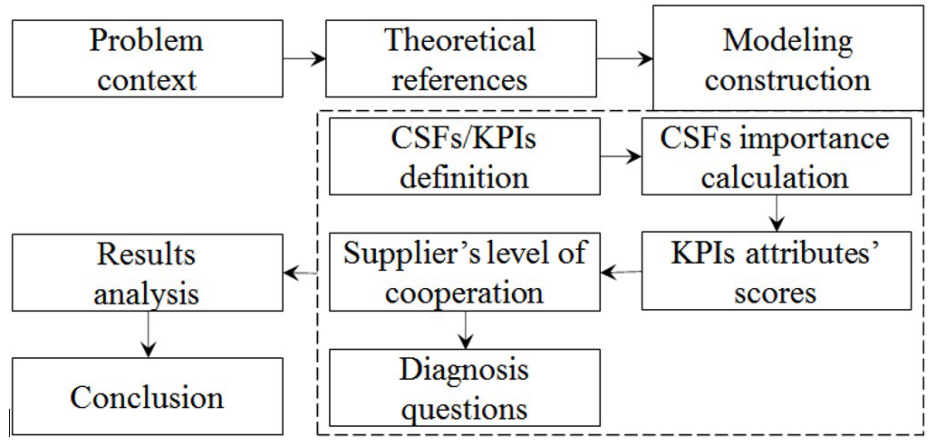

Figure 1. Research protocol.

to extensive databases with scientific articles about lean supply chain, supply chain information management, risk-sharing contracts in the supply chain, and analytic hierarchy process.

The modeling construction (Section 4) aims to develop a performance system to measure the cooperation level between an agro-industrial pork slaughterhouse cooperative and input suppliers using lean supply chain management factors. The approach is based on the use of two elements: critical success factors (CSFs) and KPls, organized in a hierarchical structure based on the AHP method (Shah \& Ward, 2007; Neuenfeldt Júnior et al., 2014; Nora et al., 2016; Rigo et al., 2020). The KPls are used to detail the CSF, measuring in practice the supplier's performance regarding specific cooperation characteristics. As a research strategy, the use of AHP to organize the hierarchical structure of CSFs and KPls is justified given the intrinsic logical process involved, where the organization of complex problems with a multicriteria perspective, as verified in this research, is facilitated. In summary, the AHP addresses a complex decision-making problem, subdivided into parts developed individually to later be aggregated and constitute the final problem solution (Saaty, 1990), which is to measure the cooperation between an agro-industrial pork slaughterhouse cooperative and input suppliers.

In the last part of the construction modeling, a diagnosis with closed questions was proposed to collect the KPls' attribute scores and the CSF importance through direct contact with the input suppliers.

The results analysis (Section 5) begins with the presentation of the chosen scenario to apply the constructed modeling proposed in the research. Then, measurement of the lean supply management cooperation level from suppliers who agreed to be investigated is described in detail, from the CSF importance calculation to the discussion on the relation between the proportion of discards and the cooperation level. Some suggestions for improvement are presented to suppliers who presented low cooperative performance with the agro-industrial pork slaughterhouse cooperative under study.

For the scenario study, the industry in which the modeling constructed was applied is a large agro-industrial pork slaughterhouse cooperative with 14 units located in Brazil. The main cooperative products are processed, cured, smoked, fresh, refined, and cooked meats. The specific cooperative unit chosen for this study produces a total of 30 products, using 196 inputs from 29 external suppliers. For example, casings for inlay, primary, and secondary packaging, ties, and staples are some inputs provided by external suppliers.

All data collection was collected from January to December 2018, obtained using the cooperative's information technology management system with the assistance of the warehouse sector. The research application was developed to input suppliers from a specific production system sector, chosen based on the consumption of inputs and discard data, such as the volume of consumption, the volume of discards, the total cost of discards, and the proportion of discards by volume consumed in production, recorded in percentages.

Finally, in the conclusion (Section 6) some remarks, limitations, and future directions are presented about the research conducted.

\section{Theoretical references}

\subsection{Lean supply chain}

Supply chain management comprises the planning and control of operations included in the supply and purchasing inputs, strongly influencing organizational performance (Bastas \& Liyanage, 2018). Supply chain management facilitates the integration between customers, the distribution network, the organizations' internal 
activities, and suppliers. Lean principles are applicable throughout the supply chain to reduce wastes, leading to a concept known as lean supply chain management (Ruiz-Benitez et al., 2018).

Successful companies often expand and link internal improvement processes to external customers and suppliers. The lean supply chain management principles are applicable in the supply chain from the supplier to the final delivery to the customer. Therefore, the focus of supply chain management practices should shift from functional and independent initiatives to general and integrative initiatives, where the promotion of an integrated and collaborative relationship between agents in the chain is fundamental to achieve management benefits, allowing a flow of goods, services, and technologies without waste (Frohlich \& Westbrook, 2001; Grasso, 2005; Vitasek et al., 2005; Womack \& Jones, 2005; Goldsby et al., 2006; Cox et al., 2007; Wee \& Wu, 2009; Marodin \& Saurin, 2013; Wiengarten et al., 2013; Neuenfeldt Júnior et al., 2015; Galankashi \& Helmi, 2016; Rezende et al., 2016; Qi et al., 2017; Ruiz-Benítez et al., 2018; Tortorella et al., 2019; Borges et al., 2020).

Lean supply chain practices can vary for different market segments. However, the minimization of activities without added value is a basic premise for a competitive supply chain (Antony et al., 2012), integrating a unified system to provide valuable products to customers through continuous improvement and elimination of waste (Grasso, 2005).

Thus, supply chain management coordination is classified into two types: internal and external. The internal coordination is focused on planning and coordinating productive activities to reduce costs. The structuring of practices and processes synchronized with suppliers and customers is developed by external coordination (Arshinder et al., 2008; Stank et al., 2011; Huo et al., 2015; Huo, 2021).

The adoption of lean principles for supply chain management activities is not a simple process, due to several reasons. Examples are that (a) losses are better identified and quantified within the industry than in the supply chain as a whole; and (b) supply chain management requires the attention of all agents in the chain, from suppliers to customers (Hines et al., 2004; Anand \& Kodali, 2008, Soni \& Kodali, 2012). Thus, the integration of suppliers and customers appears to be an important element to improve competitiveness beyond organizational limits, and therefore, efficient information flow from the final consumer to all levels of the chain is essential for each agent to convert data into valuable information (Flynn et al., 2010, Frazzon et al., 2015).

\subsection{Supply chain information management}

Successful industries have something in common; the use of information and information technology to improve the customer's responsiveness, which is fundamental to improve supply chain management efficiency. Raweewan \& Ferrell Junior (2018) assumed that information sharing is fundamental and may be the cause of many failures in the coordination of the supply chain.

Cao et al. (2010) proposed a model for the coordination of the supply chain that contains seven evaluation elements, with the first element of the model being the analysis of information sharing. Wang et al. (2014) concluded that trust is essential for success when sharing information. Jeng \& Tzeng (2012) argue that the lack of information sharing is one of the largest records of failures in the various supply chain management practices currently applied, generating a lack of confidence between partners. Therefore, Stank et al. (2011) highlight the importance of collaboration and information sharing between agents in the supply chain, being a fundamental strategy to improve the efficiency and overall performance of the supply chain. Finally, for li et al. (2018), coordination with suppliers is achieved through bilateral relations of trust.

An important supplier can be directly involved in the development of projects or work on the production system. Ideal coordination involves the planning of procedures and activities in a collaborative and synchronized way to satisfy the demands of the final customer (Flynn et al., 2010).

\subsection{Risk-sharing contracts in the supply chain}

Currently, competition in the markets and the increasing attention of customers to factors such as price, quality, delivery time, and variety of products are fundamental to supply chain management. Even with strong variations in customer demand, supply contracts can be used to improve the competitiveness of the supply chain through the application of strategies such as wholesale price contracts (WPC), revenue sharing contracts (RSC), repurchase contracts (BBC), or quantity discount contracts (QDC) (Seifbarghy et al., 2015).

Chen et al. (2006) and Xiao \& Yang (2009) used risk-sharing contracts to decrease the losses of manufacturers (overproduction) and retailers (excess inventory) under uncertain demand. Kim (2013) studied a bilateral contract with the flexibility of the number of orders as a risk-sharing mechanism to forecast demand. Shi \& Bian (2009) 
studied the effects of profit sharing and quantity discount contracts for supply chain partners. Previously, Abad (1994) and Li et al. (2017) considered cooperation in a seller-buyer supply chain to help find the ideal size and price for the sales lot. Jaber \& Osman (2006) and Heydari et al. (2017) investigated a supply chain between suppliers and retailers considering the delay in payment and the quantity discount using a profit-sharing contract.

\subsection{Analytic hierarchy process}

The main performance measurement objective is to assess the status of system and processes into an organization, based on monitoring indicators organized in a systematic structure (lvanov \& Avasilcăi, 2014; Rigo et al., 2020). A fundamental performance measurement assumption is that any tangible or intangible variables are measurable in practice (Barboza et al., 2013). The challenge is to design and apply the best metric according to each variable's characteristics.

The metrics of each variable are transformed into numbers that can be analyzed by implementing quantitative techniques able to incorporate aspects such as intensity, associations, and forecasting (Siluk et al., 2017; Costa et al., 2018; Neuenfeldt Júnior et al., 2018). In the context of the present research, the variables are represented by factors of lean supply chain management used to measure the cooperation between an agroindustrial pork slaughterhouse cooperative and input suppliers.

Inserted in the context of performance measurement, the decision-making process is structured in a hierarchical structure, analyzed holistically, identifying factors and solutions. To establish the hierarchical structure, the objective must be located in the upper node and the factors organized in levels below the upper node (Saaty, 1990; Saaty \& Vargas, 2012). One of the most important decision-making procedure is the analytic hierarchy process (AHP).

The AHP is a logical process of analyzing alternatives through a multicriteria perspective (Saaty, 1990; Dong \& Cooper, 2016; Saaty \& Vargas, 2012). Synthetically, AHP addresses a complex decision-making process, subdivided into smaller parts solved individually, to be subsequently aggregated to calculate the final solution. The decision-making process consists of recognizing the problem to be solved, in a hierarchical structure, and identifying factors that may be impacting to solve the problem.

As examples of the application of AHP in the agro-industrial context, Żak (2015) presents a comparative analysis of problems in the selection of suppliers, formulated with multiple classification problems of hierarchical criteria through AHP. Neves (2010) used video footage to record the behavior of 14,000 chickens, evaluated using AHP to estimate the feeder's efficiency.

\section{Modeling construction}

Lean supply chain CSFs were established based on the literature review presented and on the information obtained by the agro-industrial pork slaughterhouse cooperative managers, as shown in Table 1.

A hierarchical structure based on Saaty (1990) and Saaty \& Vargas (2012) was developed to verify the dependency relation between CSFs and KPls. The alternatives were replaced by KPIs, and criteria by CSFs.

Table 1. CSF description.

\begin{tabular}{|c|c|c|}
\hline CSF & Description & Authors \\
\hline Information sharing & $\begin{array}{l}\text { Create bonds of trust to establish a culture of information sharing between } \\
\text { the agro-industrial slaughterhouse cooperative and suppliers, improving } \\
\text { supply chain coordination, reducing costs in processes, stocks, and logistics, } \\
\text { increasing competitiveness. }\end{array}$ & $\begin{array}{l}\text { Cao et al. (2010), } \\
\text { Stank et al. (2011), } \\
\text { Raweewan \& Ferrell Junior } \\
\text { (2018) }\end{array}$ \\
\hline Risk sharing & $\begin{array}{l}\text { Signing contracts with clauses stipulated to the supplier to guarantee the } \\
\text { delivery of quantity, quality, and volume of inputs contracted, where } \\
\text { non-compliances are penalized. In return, the agro-industrial slaughterhouse } \\
\text { cooperative takes the risk of buying a high volume of inputs and maintaining } \\
\text { a purchasing link with the supplier for the time stipulated in the contract. }\end{array}$ & $\begin{array}{l}\text { Chen et al. (2006), } \\
\text { Xiao \& Yang (2009), } \\
\text { Seifbarghy et al. (2015), } \\
\text { Zhou et al. (2018) }\end{array}$ \\
\hline Costs x quality & $\begin{array}{l}\text { Meet the challenge of reducing costs without affecting the inputs' quality, } \\
\text { where the lack of quality generates additional costs. When the input fails, } \\
\text { defects must be corrected. Non-conforming in the input's quality resulting in } \\
\text { reworks, increasing costs, and reducing the product's added value. }\end{array}$ & lyer et al. (2019) \\
\hline Communication & $\begin{array}{l}\text { Communication between the agro-industrial slaughterhouse cooperative } \\
\text { and its suppliers supports the cooperation, contributing to a win-win } \\
\text { relationship. }\end{array}$ & Vanpoucke et al. (2014) \\
\hline
\end{tabular}


After developing potential KPls based on literature review concepts presented in Section 3 and Table 1, a semi-structured diagnosis with one open question (suggestion of other KPls) and closed questions (one for each $\mathrm{KPI}$ ) about how to measure each CSF in practice using lean supply chain management was submitted to agroindustrial pork slaughterhouse cooperative managers from production, industrial warehouse, productivity, and quality control areas. All KPls were composed of intrinsic characteristics existing in each CSF and can positively or negatively influence the cooperation level between suppliers and the agro-industrial pork slaughterhouse cooperative. As the diagnosis results, a total of 14 lean supply chain KPls were used to respond to specific CSF characteristics (Table 2).

Table 2. KPls definition by CSF.

\begin{tabular}{|c|c|}
\hline CSF & KPls \\
\hline \multirow[t]{4}{*}{ Information sharing } & $\begin{array}{l}\text { 1. Efficiency in sharing pertinent information about the products to be produced by the agro-industrial slaughterhouse } \\
\text { cooperative. }\end{array}$ \\
\hline & 2. Sharing information about future line-out products. \\
\hline & 3. A clear description of the supply expectations. \\
\hline & 4. Supplier's trust in exposing the necessary inputs' confidential data. \\
\hline \multirow[t]{2}{*}{ Risk sharing } & 5. Delivery time meets the contracted expectations. \\
\hline & 6. Equality in the contract's compliance between supplier and agro-industrial slaughterhouse cooperative. \\
\hline \multirow[t]{5}{*}{ Costs x quality } & 7. The agro-industrial slaughterhouse cooperative is receptive to the innovations proposed by the supplier. \\
\hline & 8. The agro-industrial slaughterhouse cooperative is open to developing improvement projects with the supplier. \\
\hline & $\begin{array}{l}\text { 9. The agro-industrial slaughterhouse cooperative provides data to facilitate the identification of input's non- } \\
\text { conformities. }\end{array}$ \\
\hline & 10. The supplier is following the agro-industrial slaughterhouse cooperative quality policy. \\
\hline & $\begin{array}{l}\text { 11. The supplier knows the inputs' impacts on the production system and the agro-industrial slaughterhouse } \\
\text { cooperative's customers. }\end{array}$ \\
\hline \multirow[t]{3}{*}{ Communication } & $\begin{array}{l}\text { 12. The agro-industrial slaughterhouse cooperative promotes technical visits to integrate the supplier into the } \\
\text { production system. }\end{array}$ \\
\hline & 13. Communication is effective and meets the supplier's expectations. \\
\hline & 14. The agro-industrial slaughterhouse cooperative meets the agreed negotiations deadlines. \\
\hline
\end{tabular}

The cooperation level is calculated using the score of the KPls attributes, based on the quantitative characteristics of each supplier. Another necessary variable is the CSF importance. In practice, regardless of the problem addressed, equal importance for factors located at the same level of the hierarchical structure is not common, where some CSFs have a greater impact on the goal than others. The values for the CSF importance were distributed bases on arguments verified in the scientific literature on the topic and the point of view of the supplier's managers.

Based on the arguments proposed in Chen et al. (2006), Xiao \& Yang (2009), Cao et al. (2010), Stank et al. (2011), Seifbarghy et al. (2015), Raweewan \& Ferrell Junior (2018), and Zhou et al. (2018), as the CSFs are at the same level of the hierarchical structure, the sum of all CSF importance must be equal to $100 \%$. For the Information Sharing and Risk Sharing CSFs, greater importance was attached. This is because the Information Sharing CSF increases the coordination of the production chain and the trust between all companies involved. On the other hand, Risk Sharing CSF offers advantages to comply with the supply agreements, being a fundamental element to improve the cooperation level between the supplier and the agro-industrial pork slaughterhouse cooperative. The Information Sharing and Risk Sharing CSFs are essential for lean supply chain cooperation. Thus, $60 \%$ of the total importance was distributed equally among the Information Sharing and Risk Sharing CSFs.

In this way, the remaining 40\% of importance was distributed between the Communication and Costs $x$ Quality CSFs according to the importance given by the surveyed suppliers. The importance calculation for the Communication and Costs $x$ Quality CSFs is based on the AHP pairwise comparison $\mathrm{a}_{\mathrm{ij}}$, filled by the point of view of the supplier's managers and calculated according to matrix A shown in Equation 1.

$$
A=\left[\begin{array}{ll}
a_{11} & a_{12} \\
a_{21} & a_{22}
\end{array}\right]
$$

The variables $\mathrm{a}_{11}, \mathrm{a}_{12}, \mathrm{a}_{21}$, and $\mathrm{a}_{22}$ represent the numerical pairwise comparison between the Communication $(i, j=1)$ and the Costs $x$ Quality $(j, i=2)$ CSFs, collected on a scale going from zero to ten points, named as the original scale. To adapt to the AHP, the original scale is converted to the fundamental scale proposed by Saaty (1990) through linear interpolation. Thus, the CSF importance $\left(\mathrm{w}_{\text {fcsf }}\right)$ is the sum of the judgments for each row 
in matrix A, calculated in proportion to the total value found for the sum of the judgments of the two CSFs, as shown in Equations 2 and 3 for Communication $\left(\mathrm{w}_{3 \mathrm{f}}\right)$ and Costs $x$ Quality $\left(\mathrm{w}_{4 \mathrm{f}}\right)$ CSFs, respectively.

$$
\begin{aligned}
& w_{3 f}=\frac{\sum_{j=1}^{2} a_{1 j}}{\sum_{i=1}^{2} \sum_{j=1}^{2} a_{i j}} \\
& w_{4 f}=\frac{\sum_{i=1}^{2} a_{2 j}}{\sum_{i=1}^{2} \sum_{j=1}^{2} a_{i j}}
\end{aligned}
$$

The $\mathrm{f}$ index represents each supplier interviewed during the performance measurement application stage. The fcs is the CSF index, with $\mathrm{fcs}=1$ reserved for the Information Sharing CSF, fcs $=2$ for the Risk Sharing CSF, fcs $=3$ for the Communication CSF, and fcs $=4$ for the Costs $x$ Quality CSF. As the pairwise comparison is developed individually for the opinions of each supplier, the CSF aggregated importance is given by an additive function $\left(\mathrm{w}_{\mathrm{fcs}}\right)$, as shown in Equation 4.

$$
\mathrm{w}_{\mathrm{fcs}}=\sum_{\mathrm{f}=1}^{\mathrm{n}} \delta_{\mathrm{f}} \mathrm{xw}_{\mathrm{fcsf}}
$$

The supplier's level of relevance $\delta_{\mathrm{cd}}$ is equal to 1 , regardless of the volume of inputs supplied or quantity of discards. As the Communication and Costs x Quality CSFs represent 40\% of the total CSF importance, the aggregated importance must be multiplied by 0.4. Thus, the importance of the Information Sharing and Risk Sharing CSFs is equal to $30 \%\left(\mathrm{w}_{1}=0.3\right.$ and $\left.\mathrm{w}_{2}=0.3\right)$, and the importance of the Communication and the Cost x Quality CSFs are calculated based on the manager's opinion from the suppliers.

The attributes' scores related to the suppliers' perception of cooperation are collected based on the $14 \mathrm{KPls}$. A minimum score of 0 can be assigned when the level of cooperation is low. On the other hand, the maximum score of 10 points is attributed when the perception of cooperation between supplier and agro-industrial pork slaughterhouse cooperative reaches high levels, with high degrees of maturity in the trust between both sides and the confidence in the treatment of information. Intermediate values between the minimum and maximum follow the characterized levels of cooperation logic. The arithmetic mean of the KPl attribute's score ( $\left.\mathrm{v}_{\mathrm{kpif}}^{\prime}\right)$ is used to identify each CSF cooperation score $\left(\mathrm{v}_{\text {fcsf }}\right)$, based on KPls contained in a specific CSF. The kpi $(\mathrm{kpi}=\{1,2, \ldots, 14\})$ index is used to identify each KPl attribute's score measured in each supplier $\mathrm{f}$.

The lean supplier's level of cooperation consists to aggregate the cooperation score from suppliers in the CSF $\left(v_{\text {fcsf }}\right)$ relativized according to the CSF importance ( $\left.\mathrm{w}_{\mathrm{fcs}}\right)$. Thus, the supplier's level of cooperation $\left(\mathrm{IC}_{\mathrm{f}}\right)$ is calculated by Equation 5.

$$
\mathrm{IC}_{\mathrm{f}}=\sum_{\mathrm{fcs}=1}^{4} \mathrm{v}_{\mathrm{fcs}} \mathrm{xw}_{\mathrm{fcs}}
$$

The cooperation level is expressed on a scale from a minimum performance equal to 0 to a maximum performance equivalent to 10 . To facilitate the analysis and understanding of the results obtained and to contextualize the proposed measurement, the cooperation level is converted into a qualitative scale, separated into four levels: non-cooperative $\left(0 \leq \mathrm{I}_{\mathrm{cd}} \leq 0.40\right)$; partially cooperative $\left(0.40<\mathrm{I}_{\mathrm{cd}} \leq 0.80\right)$; potentially cooperative $\left(0.80<\mathrm{I}_{\mathrm{cd}} \leq 0.95\right)$; and fully cooperative $\left(0.95<\mathrm{I}_{\mathrm{cd}} \leq 1\right)$. The assignments of these limits were structured according to the authors' experience and expectations during the development of the cooperation measurement system between agro-industrial pork slaughterhouse cooperatives and suppliers.

A diagnosis with closed questions was proposed to collect the KPls' attribute scores and the CSF importance through direct contact with the input suppliers. All answers are given by managers (analysts, supervisors, or managers) from the suppliers who work directly with the agro-industrial pork slaughterhouse cooperative in the study, allowing a real perception of the cooperation level and CSF importance.

\section{Results analysis}

\subsection{Cooperation level measurement results}

The industry in which the constructed modeling was applied is a large agro-industrial pork slaughterhouse cooperative with 14 units located in Brazil, referred to in this section as "cooperative". Table 3 shows the data for the production system sectors evaluated, where the "Cooked" sector was selected to measure the cooperation 
Table 3. List of industrial sectors classified by the proportion of discards.

\begin{tabular}{ccc}
\hline Sector & Cost of discards & Proportion of discards \\
\hline Cooked & U\$ 1,960,106.07 & $55.29 \%$ \\
Smoked & U\$ 200,501.56 & $15.46 \%$ \\
Cured & U\$ 235,039.18 & $15.32 \%$ \\
Salty & U\$ 170,242.72 & $7.04 \%$ \\
Fresh & U\$ 235,594.33 & $6.16 \%$ \\
Refined & U\$ 30,239.66 & $0.72 \%$ \\
\hline
\end{tabular}

Table 4. List of cooked sector inputs classified by suppliers and the proportion of discards.

\begin{tabular}{|c|c|c|c|c|}
\hline Input & Supplier & Volume of discards & Cost of discards & Proportion of discards \\
\hline Boxes & $A$ & $6,523.00$ units & U\$ $1,190.62$ & $1.50 \%$ \\
\hline Ribbon & $B$ & $3,117.47 \mathrm{~m}$ & U\$ 36.46 & $0.40 \%$ \\
\hline Boxes & C & 684.00 units & U\$95.66 & $0.30 \%$ \\
\hline Boxes & C & 713.00 units & U\$ 116.65 & $0.80 \%$ \\
\hline Boxes & C & 124.00 units & U\$ 35.42 & $0.40 \%$ \\
\hline Boxes & $D$ & 645.00 units & U\$ 153.72 & $0.90 \%$ \\
\hline Packaging & $E$ & 25.50 units $(x 1000)$ & U\$ $1,361.27$ & $8.60 \%$ \\
\hline Packaging & E & 3.75 units $(x 1000)$ & U\$ 219.67 & $4.40 \%$ \\
\hline Packaging & $\boldsymbol{E}$ & 9.02 units $(x 1000)$ & U\$ 510.10 & $1.60 \%$ \\
\hline Packaging & $\boldsymbol{E}$ & 2.95 units $(x 1000)$ & U\$ 143.11 & $7.90 \%$ \\
\hline Packaging & $F$ & 21.05 units $(\mathrm{x} 1000)$ & U\$ $1,187.78$ & $3.60 \%$ \\
\hline Hangtags & G & 20.27 units (x1000) & U\$ 90.90 & $2.40 \%$ \\
\hline Ribbon & $H$ & $0.68 \mathrm{~m}$ & U\$ 0.01 & $0.00 \%$ \\
\hline Packaging & $I$ & 7.77 units $(x 1000)$ & U\$ 501.93 & $1.40 \%$ \\
\hline Clip & $J$ & 10.85 units $(x 1000)$ & U\$ 54.90 & $3.30 \%$ \\
\hline Cord & $J$ & 32.23 units $(x 1000)$ & U\$ 175.02 & $2.10 \%$ \\
\hline Clip & $J$ & 7.81 units $(x 1000)$ & U\$ 53.95 & $3.70 \%$ \\
\hline Clip & $J$ & 58.31 units $(\times 1000)$ & U\$ 323.58 & $2.40 \%$ \\
\hline Label & $K$ & 18.26 units $(x 1000)$ & U\$ 691.72 & $6.30 \%$ \\
\hline Seal & $L$ & 8.03 units $(x 1000)$ & U\$ 33.74 & $0.30 \%$ \\
\hline Cord & $M$ & 0.55 units $(\mathrm{x} 1000)$ & U\$ 3.00 & $1.10 \%$ \\
\hline Clip & $M$ & 0.34 units $(\mathrm{x} 1000)$ & U\$ 2.33 & $3.30 \%$ \\
\hline Clip & $M$ & 6.18 units (x1000) & U\$ 39.36 & $3.00 \%$ \\
\hline Ribbon & $N$ & $9.42 \mathrm{~m}$ & U\$ 19.41 & $18.00 \%$ \\
\hline Packaging & $o$ & 16.70 units $(x 1000)$ & U\$ 1079.12 & $2.90 \%$ \\
\hline Packaging & $o$ & 15.95 units $(x 1000)$ & U\$ 1068.25 & $3.40 \%$ \\
\hline Packaging & $o$ & 0.17 units $(x 1000)$ & U\$21.14 & $0.50 \%$ \\
\hline Gut & $P$ & $137.27 \mathrm{~m}$ & U\$ 43.57 & $0.60 \%$ \\
\hline Gut & $P$ & $3,231.78 \mathrm{~m}$ & U\$ 964.61 & $0.50 \%$ \\
\hline Gut & $P$ & $3,534.97 \mathrm{~m}$ & U\$ 1142.39 & $3.40 \%$ \\
\hline Packaging & $Q$ & 14.37 units $(x 1000)$ & U\$ 928.53 & $2.50 \%$ \\
\hline
\end{tabular}

between the agro-industrial pork slaughterhouse cooperative and the input suppliers based on the highest proportion of input discards.

In the "Cooked" sector, eight products are industrialized, using 53 inputs obtained by 21 registered suppliers. However, during the year, 22 inputs did not present discards. As a consequence, a total of 31 inputs are representative, provided by 17 suppliers. The list of inputs classified by suppliers and by the proportion of discards are shown in Table 4.

The "Cooked" sector proportion of discards is caused by the differentiated product mix, mainly due to the variety of packaging used. In particular, packaging is one of the main inputs to preserve the integrity of the products, in addition to providing a better visual aspect to the final consumer. For slaughterhouse production lines, packaging without conformity causes product reprocessing, rework of labor, and non-compliance with the production quotas. Also, the non-conformities identified by the customer can damage the slaughterhouse's reputation. 
For the analysis, nine suppliers, $B(\mathrm{f}=1), D(\mathrm{f}=2), E(\mathrm{f}=3), J(\mathrm{f}=4), K(\mathrm{f}=5), L(\mathrm{f}=6), N(\mathrm{f}=7), O(\mathrm{f}=8)$, and $Q(\mathrm{f}=9)$, responsible for supplying boxes, packaging, staples, labels, seals, and tapes, agreed to participate in the measurement of the cooperation level with the cooperative, marked in bold in Table 4.

To obtain the importance of the Costs $x$ Quality and Communication CSFs, the calculations were performed and the relative amounts found were 19\% and 21\%, respectively. Thus, $100 \%$ of the CSF importance was determined, considering 30\% for the Information Sharing CSF and 30\% for the Risk Sharing CSF, according to the constructed modeling.

With the KPls' attribute scores and the CSF importance, the suppliers' levels of cooperation with the cooperative were calculated, as shown in the graph in Figure 2. The bars represent the levels of cooperation obtained for each supplier, where red, yellow, or green, means respectively, the partially cooperative, potentially cooperative, or fully cooperative levels. The blue line indicates the proportion of discards for each supplier.

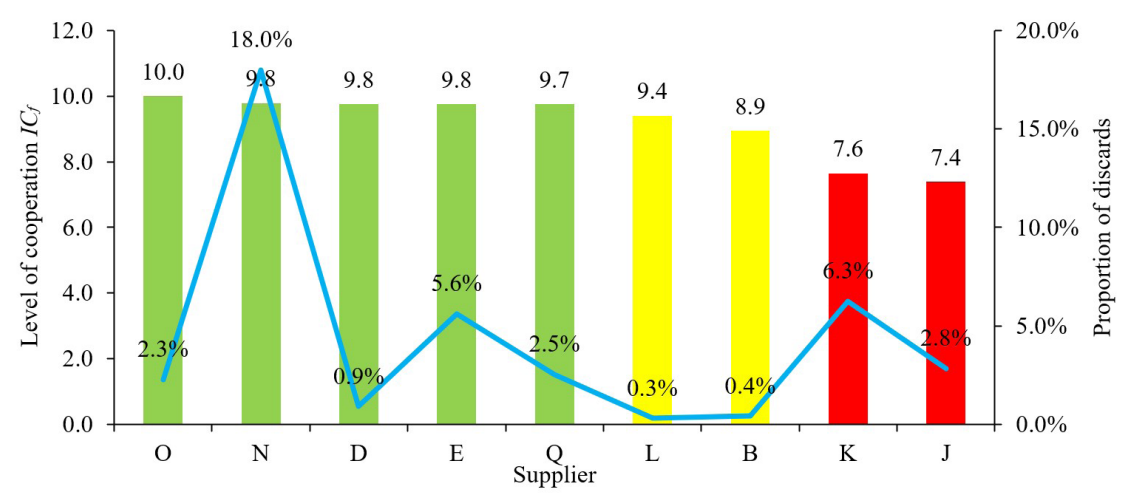

Figure 2. Supplier's level of cooperation performance.

In general, the suppliers obtained a satisfactory level of cooperation, with $77.80 \%$ of suppliers being potentially $(L$ and $B)$ or fully $(O, N, D, E$, and $Q)$ cooperative, maintaining a prosperous, trusting, transparent, and open relationship with the cooperative. Instead, $22.20 \%$ of suppliers are partially cooperative ( $K$ and $J$ ), with the lowest performance level for the Information Sharing CSF.

Supplier $J$, who provides one type of cord and three types of clip for product inlay, obtained an overall score of 7.4 being non-cooperative $\left(\mathrm{v}_{14}=4.8\right)$ in the Information Sharing CSF. In a production system for cooked products, the stapling and inlay processes are performed using machines of one specific brand, which operate with higher performance when the cord and clips used are ones provided by the machine brand supplier. Supplier $J$ is not able to supply cord and clips that are ideal for the machine's configurations, although they are able to supply alternative models at an affordable price. These non-compatibilities cause production problems, as machines stop, and product loss occurs as they fall on the floor. Given this production problem, the cooperative is gradually reducing the volumes of inputs supplied by the supplier $J$, affecting the performance observed in KPI 2 (Sharing information about future line-out products), $v_{24}^{\prime}=4.0$, and KPI 7 (The agro-industrial slaughterhouse cooperative is receptive to innovations proposed by the supplier), $v_{74}^{\prime}=3.0$.

Supplier $K$ adopts anticipation supply practices, where the input (label) is manufactured by the supplier in larger volumes, being able to deliver quantities of labels greater than the orders requested by the cooperative, causing inconvenience mainly when the cooked production mix changes frequently. The swine fever in China, which reduced Chinese production of cooked products by 35\%, intensifying Brazilian exports, which suddenly changed the mix of cooperative cooked production to meet the demands of the Chinese market. As a consequence, a large number of labels for other cooked products supplied in advance were kept in stock for several months.

The global demand for cooked pork meat grew over the last years for both domestic and exportation markets, frequently changing the production mix, where supplier $K$ produced labels for a lower demand of cooked products. Consequently, the cooperative should not receive an excess of labels from supplier $K$, causing losses that influence the low performance verified for KPI 2 (Share information about future line-out products), $\mathrm{v}_{25}=3.0$.

\subsection{Discussion}

A well-designed supply chain must operate by delivering products quickly to customers with minimal waste. The results contributed to identifying the suppliers with greater and lesser potential for collaboration with the 
cooperative. As described by lyer et al. (2019), a higher level of collaboration leads to an increase in the quality of services provided by the supplier, where wastes related to costs are reduced, positively affecting the production efficiency, making the supply chain more competitive.

As a lean supply chain management requirement, based on the level of cooperation measured for all suppliers studied, a full competitive cooperation performance is directly linked to a performance score for the Risk Sharing CSF and, mainly, for the Information Sharing CSF, converging with the literature. According to Cao et al. (2010), sharing information in the supply chain context improves the production system processes, stocks, and logistics, reducing operational costs and increasing the competitiveness for all supply chain stakeholders.

This issue is rapidly gaining importance for supply chain managers to increase the efficiency of cooked production lines to attend all markets' demands. Following Ziggers \& Trienekens (1999), Flynn et al. (2010), and Jasti \& Kodali (2015), the results obtained showed consequences of the relation between suppliers and the cooperative. A level of cooperation helps substantially to sell more products with high profitably, as the inputs are designed together with the supplier, reducing the chances of non-conformity rejections and production reworks, in a similar manner as described by Shi \& Bian (2009). Thus, the operational costs for the cooperative and suppliers are reduced, as the supplier also increases its production system efficiency, contributing to the reduction of downtime in the cooperative's production line. Finally, another positive consequence of an established relation between a supplier and a cooperative is the programmed obsolescence or input adjustment based on the demand dynamics of the consumer markets, avoiding stocks of inputs that operationally can no longer be allocated to products that have suffered a reduction or discontinuation of sales, following Abad (1994).

As verified by the results in Figure 2, a non-direct relation between the level of cooperation and the proportion of discards can be seen. Suppliers $K$ and $J$ are partially cooperative $\left(\mathrm{IC}_{5}=7.6\right.$ and $\left.\mathrm{IC}_{4}=7.4\right)$ and are responsible for different proportions of discards (6.30\% and 2.80\%, respectively). Supplier $N$ supplies only one input (ribbons), consumed in low volume, with the highest proportion of discards (18\%), despite being fully cooperative $\left(\mathrm{IC}_{7}=9.8\right)$. Also, suppliers $L$ and $B$ are potentially competitive $\left(\mathrm{IC}_{6}=9.4\right.$ and $\left.\mathrm{IC}_{2}=8.9\right)$, being responsible for low proportions of discards $(0.30 \%$ and $0.40 \%$, respectively). Thus, the proportion of discards varies according to the input's volume of consumption in the production system, regardless of the supplier's level of cooperation or the total number of discards per day or month.

The most wasted inputs are the most complex to be used during production, or inputs that do not satisfy the minimum technical requirements required to produce embedded cooked products. The impacts of discard each input in the production system are different, where most of the discarded inputs do not cause significant financial costs and interruptions. Suppliers $O$ and $Q$ are classified as fully cooperative, with a low proportion of discards to supply cardboard boxes, which is one of the main inputs used responsible for maintaining the cooked product's integrity and characteristics. The cardboard boxes with non-conformities require rework to assemble a new box to replace the discarded cardboard box. Compared to staples used to produce embedded cooked products, the losses from discarded cardboard boxes are much higher. Therefore, strategically for the cooperative, it is important to maintain established levels of cooperation with suppliers responsible for the supply of inputs that affect the productive system severely, improving the productive efficiency and reducing financial costs.

As a practical implication, 55.6\% of the suppliers studied are considered fully cooperative. This level of cooperation is relevant, revealing opportunities to maintain the good relationship with relevant suppliers in the context of the cooperative's production system for cooked products. At the same time, the results obtained indicates that a significant improvement in the relationship with $44.4 \%$ of the suppliers is essential to improve the products' quality. Therefore, suggestions to improve the supplier's level of cooperation performance between the cooperative and the worst evaluated suppliers are proposed in the next section.

\subsection{Improvement suggestions}

For suppliers $K$ and $J$, the KPls with the lowest performance were identified to propose solutions that, if implemented, can improve the supplier's level of cooperation performance. Thus, Table 5 shows some actions to improve the factors responsible for reducing the performance of the cooperation, which are KPls 2, 4, 7, and 12. The attributed score equal to 9 for the expected performance $\left(\mathrm{v}_{\mathrm{kpif}}^{\prime}\right)$ was defined as a reference of expected performance based on the general KPls' performance scores verified for the other suppliers classified as potentially or fully competitive.

For KPl 2 (Share information about future line-out products), the cooperative complies with the input contracts, receiving and using all agreed inputs. Thus, the proposed action is to change the supplier's perception to avoid not-agreed inputs or to keep line-out products input stocks in the suppliers' warehouses. For KPI 4 (Supplier's trust in exposing the necessary inputs' confidential data), poor performance was obtained due to 
Table 5. Lower performance KPls and suggestions for improvement actions.

\begin{tabular}{|c|c|c|c|c|}
\hline & \multicolumn{2}{|c|}{$\begin{array}{l}\text { Current performance } \\
\left(\boldsymbol{v}_{k p i f}^{\prime}\right)\end{array}$} & \multirow[t]{2}{*}{ Suggested actions } & \multirow{2}{*}{$\begin{array}{l}\text { Expected performance } \\
\qquad\left(\boldsymbol{v}_{\text {kpi } \boldsymbol{f}}^{\prime}\right)\end{array}$} \\
\hline & Supplier $K$ & Supplier J & & \\
\hline KPl 2 & 6 & 4 & $\begin{array}{l}\text { Maintain suppliers informed about possible line-out products, besides guiding to } \\
\text { prevent delivery of not-agreed inputs. }\end{array}$ & 9 \\
\hline KPl 4 & 8 & 4 & $\begin{array}{l}\text { Show that the cooperative has values based on strategic management, promoting } \\
\text { a closer relationship with the supplier. }\end{array}$ & 9 \\
\hline KPl 7 & 7 & 3 & $\begin{array}{l}\text { Attend to the supplier news and innovations to improve production processes } \\
\text { and cooperation. }\end{array}$ & 9 \\
\hline KPl 12 & 6 & 4 & $\begin{array}{l}\text { Increase the number of technical visits with suppliers, increasing interaction with } \\
\text { the cooperative. }\end{array}$ & 9 \\
\hline
\end{tabular}

some instances of the suppliers not-agreeing with the cooperative, weakening the supply relationship. Rebuilding trust is a complex issue, in which consistent actions are being developed to bring suppliers and the cooperative together in the same supply chain direction.

Innovation is necessary to streamline processes and keep the cooperative competitive. However, in some situations, cost-benefit does not provide better results for the production system. As a suggestion to improve KPI 7 (The agro-industrial slaughterhouse cooperative is receptive to the innovations proposed by the supplier), the cooperative should pay attention to the supplier's innovations to improve the supply chain, specifically for the delivery of inputs to the cooperative. If the supplier's innovations are not interestg to the cooperative, an option is to contact the supplier and explain in detail why the proposed innovation is not interesting and cannot be adapted to be used in the production system.

In KPI 12 (The agro-industrial slaughterhouse cooperative promotes technical visits to integrate the supplier into the production system), suppliers with low performances feel the need to be closer to the cooperative's cooked production operations and processes. The improvement actions are relatively simple and involve the promotion of technical visits to increase the contact and relationship with the suppliers. Also, in general, KPls 2 and 7 do not demand complex actions to deal with the suggestions proposed. Instead, for KPI 4, the situation is more complex, where a trust supply relationship is difficult to be measured, requiring a long period of information exchange to reach acceptable levels of cooperation.

Based on the suggested actions proposed to improve the performance of KPls with a lower cooperative performance for suppliers $K$ and $J$, the recalculated levels of cooperation are equal to, respectively, $\mathrm{IC}_{5}=8.2$. and $\mathrm{IC}_{4}=8.7$, being potentially cooperative.

\section{Conclusion}

The present study resulted in a performance measurement tool to measure the cooperation between an agro-industrial pork slaughterhouse cooperative and input suppliers, applied in a Brazilian company.

The main contributions obtained after conduct this research were provided by the use of a systematic method for measuring the input supplier cooperation, regardless of the number of different inputs provided by the supplier. Also, the impact of information and risk-sharing contracts factors on cooperation between the agro-industrial pork slaughterhouse cooperative and input suppliers were confirmed by the results obtained after applying in practice the measurement tool developed.

The premises of waste reduction and cooperation found in lean supply chain management were fundamental to develop the CSFs and KPls to measure the cooperation between an agro-industrial pork slaughterhouse cooperative and input suppliers in practice. For the literature on supply chain management, the present study shows that waste in the supply chain can be measured by the lack of cooperation between suppliers and a cooperative, as verified for suppliers $J$ and $K$. The performance is the result of policies and procedures that drive several critical segments of the supply chain. The suppliers $O, N, D, E$, and $Q$, with the best performances, show that an intense sharing of information and risks is essential to coordinate and improve the win-win policy in lean supply chain management.

The results were presented to the cooperative managers, revealing opportunities to improve the cooperation relationship and indicating the suppliers with the best and worst levels of cooperation in the agro-industrial pork slaughterhouse cooperative supply chain context. A direct relation between a low proportion of discards and a high cooperative performance between suppliers and the analyzed cooperative was not verified. Additionally, different inputs have different demand fluctuations and different ways of handling, which can increase the proportion of discards during the production of cooked products. 
As research limitations, the inputs with the highest proportion of discards do not always cause significant financial costs and interruptions in the production system, as verified for cardboard boxes and staples. Therefore, using only the proportion of discards is not enough to make significant waste reduction actions to improve the lean supply chain management in agro-industrial pork slaughterhouse cooperatives.

For future directions, the proposed performance measurement tool can be applied in practice in any industrial sector of an agro-industrial slaughterhouse inserted in the context of lean supply chain management, regardless of the quantity and the volume of inputs of each supplier. The present authors suggest the application of the performance measurement tool in other industrial sectors (cutting room and maintenance) or different agroindustrial cooperatives.

\section{References}

Abad, P. L. (1994). Supplier pricing and lot sizing when demand is price sensitive. European Journal of Operational Research, 78(3), 334-354. http://dx.doi.org/10.1016/0377-2217(94)90044-2.

Abreu, M. F., Alves, A. C., \& Moreira, F. (2017). Lean-Green models for eco-efficient and sustainable production. Energy, $137,846-853$. http://dx.doi.org/10.1016/j.energy.2017.04.016.

Anand, G., \& Kodali, R. (2008). A conceptual framework for lean supply chain and its implementation. International Journal of Value Chain Management, 2(3), 313-357. http://dx.doi.org/10.1504/1JVCM.2008.019517.

Antony, J., Agus, A., \& Hajinoor, M. S. (2012). Lean production supply chain management as driver towards enhancing product quality and business performance. International Journal of Quality \& Reliability Management, 29(1), 92-121. http://dx.doi. org/10.1108/02656711211190891.

Arshinder, Kanda, A., \& Deshmukh, S. G. (2008). Supply chain coordination: perspectives, empirical studies and research directions. International Journal of Production Economics, 115(2), 316-335. http://dx.doi.org/10.1016/j.ijpe.2008.05.011.

Associação Brasileira das Indústrias Exportadoras de Carne - ABIEC. (2019). Beef report: perfil da pecuária no Brasil. São Paulo.

Barboza, S. 1. S., Carvalho, D. L. T., Soares Neto, J. B., \& Costa, F. J. (2013). Variações de Mensuração pela Escala de Verificação: uma análise com escalas de 5, 7 e 11 pontos. Teoria e Prática em Administração, 3(2), 99-120.

Bastas, A., \& Liyanage, K. (2018). Sustainable supply chain quality management: a systematic review. Journal of Cleaner Production, 181, 726-744. http://dx.doi.org/10.1016/j.jclepro.2018.01.110.

Borges, G. A., Tortorella, G. L., Martínez, F., \& Thurer, M. (2020). Simulation-based analysis of lean practices implementation on the supply chain of a public hospital. Production, 30, 1-16. http://dx.doi.org/10.1590/0103-6513.20190131.

Cao, M., Vonderembse, M. A., Zhang, Q., \& Ragu-Nathan, T. S. (2010). Supply chain collaboration: conceptualisation and instrument development. International Journal of Production Research, 48(22), 6613-6635. http://dx.doi.org/10.1080/00207540903349039.

Chen, H., Chen, J., \& Chen, Y. F. (2006). A coordination mechanism for a supply chain with demand information updating. International Journal of Production Economics, 103(1), 347-361. http://dx.doi.org/10.1016/j.ijpe.2005.09.002.

Costa, F. J., Orsini, A. C. R., \& Carneiro, J. S. (2018). Variações de mensuração por tipos de escalas de verificação: uma análise do construto de satisfação discente. GESTÃO. Org, 16(2), 132-144. http://dx.doi.org/10.21714/1679-18272018v16n2.p132-144.

Cox, A., Chicksand, D., \& Palmer, M. (2007). Stairways to heaven or treadmills to oblivion? British Food Journal, 109(9), 689-720. http:// dx.doi.org/10.1108/00070700710780689.

Dong, Q., \& Cooper, O. (2016). An orders-of-magnitude AHP supply chain risk assessment framework. International Journal of Production Economics, 182, 144-156. http://dx.doi.org/10.1016/j.ijpe.2016.08.021.

Flynn, B. B., Huo, B., \& Zhao, X. (2010). The impact of supply chain integration on performance: A contingency and configuration approach. Journal of Operations Management, 28(1), 58-71. http://dx.doi.org/10.1016/j.jom.2009.06.001.

Frazzon, E. M., Albrecht, A., Hurtado, P. A., Silva, L. S., \& Pannek, J. (2015). Hybrid modelling approach for the scheduling and control of integrated production and logistic processes along export supply chains. IFAC-PapersOnLine, 48(3), 1521-1526. http://dx.doi. org/10.1016/j.ifacol.2015.06.302.

Frohlich, M. T., \& Westbrook, R. (2001). Arcs of integration: an international study of supply chain strategies. Journal of Operations Management, 19(2), 185-200. http://dx.doi.org/10.1016/S0272-6963(00)00055-3.

Galankashi, M. R., \& Helmi, S. A. (2016). Assessment of hybrid Lean-Agile (Leagile) supply chain strategies. Journal of Manufacturing Technology Management, 274), 470-482. http://dx.doi.org/10.1108/JMTM-08-2015-0069.

Goldsby, T. J., Griffis, S. E., \& Roath, A. S. (2006). Modeling lean, agile, and leagile supply chain strategies. Journal of Business Logistics, 271), 57-80. http://dx.doi.org/10.1002/j.2158-1592.2006.tb00241.x.

Grasso, L. P. (2005). Are ABC and RCA accounting systems compatible with lean management? Management Accounting Quarterly, Z1), 12.

Heydari, J., Rastegar, M., \& Glock, C. H. (2017). A two-level delay in payments contract for supply chain coordination: The case of credit-dependent demand. International Journal of Production Economics, 191, 26-36. http://dx.doi.org/10.1016/j.ijpe.2017.05.004.

Hines, P., Holweg, M., \& Rich, N. (2004). Learning to evolve: a literature review of contemporary lean thinking. International Journal of Operations \& Production Management, 24(10), 994-1011. http://dx.doi.org/10.1108/01443570410558049.

Huo, B., Zhang, C., \& Zhao, X. (2015). The effect of IT and relationship commitment on supply chain coordination: A contingency and configuration approach. Information \& Management, 52(6), 728-740. http://dx.doi.org/10.1016/j.im.2015.06.007.

Huo, J. (2021). Supply chain coordination. In J. Huo (Eds.), Advances in theory and practice in store brand operations (pp. 211-253). Singapore: Springer. http://dx.doi.org/10.1007/978-981-15-9877-7_5.

Ivanov, C. l., \& Avasilcăi, S. (2014). Performance measurement models: an analysis for measuring innovation processes performance. Procedia: Social and Behavioral Sciences, 124, 397-404. http://dx.doi.org/10.1016/j.sbspro.2014.02.501. 
lyer, K. N., Srivastava, P., \& Srinivasan, M. (2019). Performance implications of lean in supply chains: Exploring the role of learning orientation and relational resources. International Journal of Production Economics, 216, 94-104. http://dx.doi.org/10.1016/j. ijpe.2019.04.012.

Jaber, M. Y., \& Osman, 1. H. (2006). Coordinating a two-level supply chain with delay in payments and profit sharing. Computers \& Industrial Engineering, 50(4), 385-400. http://dx.doi.org/10.1016/j.cie.2005.08.004.

Jasti, N. V. K., \& Kodali, R. (2015). A critical review of lean supply chain management frameworks: proposed framework. Production Planning and Control, 26(13), 1051-1068. http://dx.doi.org/10.1080/09537287.2015.1004563.

Jeng, D. J. F., \& Tzeng, G. H. (2012). Social influence on the use of clinical decision support systems: revisiting the unified theory of acceptance and use of technology by the fuzzy DEMATEL technique. Computers \& Industrial Engineering, 62(3), 819-828. http:// dx.doi.org/10.1016/j.cie.2011.12.016.

Kennedy, F. A., \& Widener, S. K. (2008). A control framework: Insights from evidence on lean accounting. Management Accounting Research, 19(4), 301-323. http://dx.doi.org/10.1016/j.mar.2008.01.001.

Kim, W. S. (2013). A supply chain contract with flexibility as a risk-sharing mechanism for demand forecasting. International Journal of Systems Science, 44(6), 1134-1149. http://dx.doi.org/10.1080/00207721.2011.653592.

Larson, T., \& Greenwood, R. (2004). Perfect complements: synergies between lean production and eco-sustainability initiatives. Environmental Quality Management, 13(4), 27-36. http://dx.doi.org/10.1002/tqem.20013.

Li, R., Chan, Y. L., Chang, C. T., \& Cárdenas-Barrón, L. E. (2017). Pricing and lot-sizing policies for perishable products with advancecash-credit payments by a discounted cash-flow analysis. International Journal of Production Economics, 193, 578-589. http:// dx.doi.org/10.1016/j.ijpe.2017.08.020.

Li, S., Zhao, X., \& Huo, B. (2018). Supply chain coordination and innovativeness: A social contagion and learning perspective. International Journal of Production Economics, 205, 47-61. http://dx.doi.org/10.1016/j.jpe.2018.07.033.

Marodin, G. A., \& Saurin, T. A. (2013). Implementing lean production systems: research areas and opportunities for future studies. International Journal of Production Research, 51(22), 6663-6680. http://dx.doi.org/10.1080/00207543.2013.826831.

Neuenfeldt Júnior, A. L., Siluk, J. C. M., \& Nara, E. O. B. (2015). Estudo de um fluxo interno de materiais baseado na filosofia Lean Manufacturing. Production, 25(3), 691-700. http://dx.doi.org/10.1590/0103-6513.112312.

Neuenfeldt Júnior, A. L., Siluk, J. C. M., Soliman, M., \& Marques, K. F. S. (2014). Study to evaluate the performance development of Brazilian franchise segments. Independent Journal of Management \& Production, 5(2), 381-397.

Neuenfeldt Júnior, A. L., Siluk, J. C. M., Soliman, M., \& Paris, S. D. (2018). Modelling for performance measurement of bus rapid transit systems in Brazil. International Journal of Logistics Systems and Management, 30(3), 283-297. http://dx.doi.org/10.1504/ IJLSM.2018.092611.

Neves, D. P. (2010). Método Analytic Hierarchy Process (AHP) para classificação de comedouros utilizados na produção de frangos de corte (Dissertação de mestrado). Universidade Estadual de Campinas, Campinas.

Nora, L. D. D., Siluk, J. C. M., Neuenfeldt Júnior, A. L., Soliman, M., Nara, E. O. B., \& Furtado, J. C. (2016). The performance measurement of innovation and competitiveness in the telecommunications services sector. International Journal of Business Excellence, 9(2), 210-224. http://dx.doi.org/10.1504/1JBEX.2016.074844.

Qi, Y., Huo, B., Wang, Z., \& Yeung, H. Y. J. (2017). The impact of operations and supply chain strategies on integration and performance. International Journal of Production Economics, 185, 162-174. http://dx.doi.org/10.1016/j.jpe.2016.12.028.

Raweewan, M., \& Ferrell Junior, W. G. (2018). Information sharing in supply chain collaboration. Computers \& Industrial Engineering, 126, 269-281. http://dx.doi.org/10.1016/j.cie.2018.09.042.

Rezende, H. A., Antunes Júnior, C. L. S., Senna, P., de Souza, L. A., \& Monteiro, A. (2016). Determination of metrics and risk mapping for the analysis of lean supply chains. Journal of Lean Systems, 1(1), 31-50.

Rigo, P. D., Rediske, G., Rosa, C. B., Gastaldo, N. G., Michels, L., Neuenfeldt Júnior, A. L., \& Siluk, J. C. M. (2020). Renewable energy problems: exploring the methods to support the decision-making process. Sustainability, 12(23), 10195. http://dx.doi.org/10.3390/ su122310195.

Ruiz-Benítez, R., lópez, C., \& Real, J. C. (2018). The lean and resilient management of the supply chain and its impact on performance. International Journal of Production Economics, 203, 190-202. http://dx.doi.org/10.1016/j.jpe.2018.06.009.

Saaty, T. L. (1990). How to make a decision: the analytic hierarchy process. European Journal of Operational Research, 48(1), 9-26. http://dx.doi.org/10.1016/0377-2217(90)90057-l.

Saaty, T. L., \& Vargas, L. G. (2012). The seven pillars of the analytic hierarchy process. In T. L. Saaty \& L. G. Vargas (Eds.), Models, methods, concepts \& applications of the analytic hierarchy process (pp. 23-40). Boston: Springer. http://dx.doi.org/10.1007/9781-4614-3597-6_2.

Seifbarghy, M., Nouhi, K., \& Mahmoudi, A. (2015). Contract design in a supply chain considering price and quality dependent demand with customer segmentation. International Journal of Production Economics, 167, 108-118. http://dx.doi.org/10.1016/j.ijpe.2015.05.004.

Shah, R., \& Ward, P. T. (2007). Defining and developing measures of lean production. Journal of Operations Management, 25(4), 785805. http://dx.doi.org/10.1016/j.jom.2007.01.019.

Shi, C., \& Bian, D. (2009). Closed-loop supply chain coordination by revenue sharing contract and quantity discount contract. In 2009 International Conference on Information Management, Innovation Management and Industrial Engineering (Vol. 2, pp. 581-584). New York: IEEE. http://dx.doi.org/10.1109/1C111.2009.298.

Siluk, J. C. M., Kipper, L. M., Nara, E. O. B., Neuenfeldt Júnior, A. L., Dal Forno, A. J., Soliman, M., \& Chaves, D. M. D. S. (2017). A performance measurement decision support system method applied for technology-based firms' suppliers. Journal of Decision Systems, 26(1), 93-109. http://dx.doi.org/10.1080/12460125.2016.1204213.

Singh, S. C., \& Pandey, S. K. (2015). Lean supply-chain: a state-of-the-art literature review. Journal of Supply Chain Management Systems, 4(3), 33. http://dx.doi.org/10.21863/jscms/2015.4.3.013.

Sjauw-Koen-Fa, A. R., Blok, V., \& Omta, S. W. F. (2016). Critical success factors for smallholder inclusion in high value-adding supply chains by food and agribusiness multinational enterprise. The International Food and Agribusiness Management Review, 19, 83-112. 
Soni, G., \& Kodali, R. (2012). Evaluating reliability and validity of lean, agile and leagile supply chain constructs in lndian manufacturing industry. Production Planning and Control, 23(10-11), 864-884. http://dx.doi.org/10.1080/09537287.2011.642207.

Stank, T. P., Dittmann, J. P., \& Autry, C. W. (2011). The new agenda for the supply chain: a synopsis and instructions for future research. International Journal of Physical Distribution \& Logistics Management, 41(10), 940-955. http://dx.doi.org/10.1108/09600031111185220.

Tortorella, G. L., Rosa, M. V. L. L., Caiado, R., Nascimento, D., \& Sawhney, R. (2019). Assessment of Lean implementation in Hotels' supply chains. Production, 29, 1-10. http://dx.doi.org/10.1590/0103-6513.20190044.

Vanpoucke, E., Vereecke, A., \& Wetzels, M. (2014). Developing supplier integration capabilities for sustainable competitive advantage: a dynamic capabilities approach. Journal of Operations Management, 32(7-8), 446-461. http://dx.doi.org/10.1016/j.jom.2014.09.004.

Vitasek, K., Manrodt, K., \& Abbott, J. (2005). What makes a lean supply chain? Supply Chain Managment Review, 9(7), 39-45.

Wang, Z., Ye, F., \& Tan, K. H. (2014). Effects of managerial ties and trust on supply chain information sharing and supplier opportunism. International Journal of Production Research, 52(23), 7046-7061. http://dx.doi.org/10.1080/00207543.2014.932931.

Wee, H. M., \& Wu, S. (2009). Lean supply chain and its effect on product cost and quality: a case study on Ford Motor Company. Supply Chain Management, 14(5), 335-341. http://dx.doi.org/10.1108/13598540910980242.

Wiengarten, F., Fynes, B., \& Onofrei, G. (2013). Exploring synergetic effects between investments in environmental and quality/lean practices in supply chains. Supply Chain Management, 18(2), 148-160. http://dx.doi.org/10.1108/13598541311318791.

Womack, J. P., \& Jones, D. T. (2005). Lean consumption. Harvard Business Review, 83(3), 58-68. PMid:15768676.

Xiao, T., \& Yang, D. (2009). Risk sharing and information revelation mechanism of a one-manufacturer and one-retailer supply chain facing an integrated competitor. European Journal of Operational Research, 196(3), 1076-1085. http://dx.doi.org/10.1016/j. ejor.2008.05.004.

Żak, J. (2015). Comparative analysis of multiple criteria evaluations of suppliers in different industries. Transportation Research Procedia, 10, 809-819. http://dx.doi.org/10.1016/j.trpro.2015.09.034.

Zhou, C., Tang, W., \& Lan, Y. (2018). Supply chain contract design of procurement and risk-sharing under random yield and asymmetric productivity information. Computers \& Industrial Engineering, 126, 691-704. http://dx.doi.org/10.1016/j.cie.2018.10.022.

Ziggers, G. W., \& Trienekens, J. (1999). Quality assurance in food and agribusiness supply chains: developing successful partnerships. International Journal of Production Economics, 60, 271-279. http://dx.doi.org/10.1016/S0925-5273(98)00138-8. 